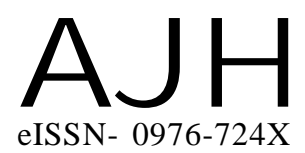

Received : 07.04.2014

Revised : 29.10.2014

Accepted : 10.11.2014
THE ASIAN JOURNAL OF HORTICULTURE

Volume 9 | Issue 2 | Dec., $2014 \mid$ |400-403

Visit us -www.researchjournal.co.in

\title{
Effect of different levels of row spacing and nitrogen on growth characters in roselle (Hibiscus sabdariffa var. sabdariffa)
}

Members of the Research Forum

Associated Authors:

Department of Horticulture, Faculty

of Agriculture, Annamalai University,

ANNAMALAINAGAR (T.N.) INDIA

Author for correspondence E.ARIVAZHAGAN

Department of Horticulture, Faculty of Agriculture, Annamalai University,

ANNAMALAINAGAR (T.N.) INDIA

Email : gskspice@gmail.com

\section{A.K. RAJA ${ }^{1}$ AND E. ARIVAZHAGAN}

ABSTRACT : The present investigation was carried out to study the effect of different levels of nitrogen and spacing on the growth characters in roselle. A field trial was conducted in a Factorial Randomized Block Design with five levels of nitrogen $\left(50,100,150,200\right.$ and $\left.250 \mathrm{~kg} \mathrm{ha}^{-1}\right)$ and three levels of row spacing $(60,90$ and $120 \mathrm{~cm})$. The results of the present study revealed that the spacing of $120 \times 75 \mathrm{~cm}$ and nitrogen application of $250 \mathrm{~kg} \mathrm{ha}^{-1}$ was found to be superior in improving the growth characters like plant height, number of branches plant ${ }^{-1}$, stem diameter, plant spread and leaf area.

KEY WORDS : Nitrogen, Spacing, Roselle, Growth

HOW TO CITE THIS ARTICLE : Raja, A.K. and Arivazhagan, E. (2014). Effect of different levels of row spacing and nitrogen on growth characters in roselle (Hibiscus sabdariffa var. sabdariffa). Asian J. Hort., 9(2) : 400-403. 